\title{
UČENJE U MUZEJU U SVETLU KONSTRUKTIVISTIČKE TEORIJSKE OSNOVE**
}

Apstrakt: U radu se polazi od stava da muzeji poseduju značajni potencijal za učenje. U skorije vreme, uticaj konstruktivističke teorije na muzej je veliki, što se naročito odražava na područje obrazovnog rada. U tom okviru, u tekstu se teorijski analizira konstruktivistički pristup obrazovanju i učenju u muzeju. Cilj rada odnosi se na razmatranje i sagledavanje mogućnosti i značaja primene konstruktivizma $u$ obrazovnom radu i procesu učenja u muzeju. Najpre se istražuju ključna polazišta konstruktivizma i daje pregled teorija baziranih na iskustvu, teorija koje su ostavile značajan trag u obrazovnoj praksi muzeja. Takođe, predstavljaju se istraživački nalazi o efektima primene konstruktivističke teorije $\mathrm{u}$ obrazovnom radu muzeja. Zaključuje se da primena konstruktivizma kao teorijske osnove obrazovnog rada $u$ muzeju donosi značajne pedagoške podsticaje: muzej se prilagođava potrebama i interesovanjima posetilaca, muzejska iskustva približavaju se svakodnevnom životu i povezuju sa njim, sadržaji se izlažu na interesantan način te se obezbeđuju autentična iskustva učenja.

Ključne reči: konstruktivizam, muzej, obrazovanje, učenje.

\section{UVOD}

Fokus delovanja današnjeg sistema obrazovanja smešten je uglavnom u formalne vaspitno-obrazovne institucije poput škole. Iako se još uvek smatra najvažnijim izvorom znanja, škola nije jedino mesto obrazovnog delovanja. Vreme u kojem živimo i učestale promene u društvu zahtevaju

\footnotetext{
*Olja Džinkić, olja.dzinkic@gmail.com

** Rad je nastao u okviru projekta Kvalitet obrazovnog sistema Srbije u evropskoj perspektivi (179010) koji finansira Ministarstvo prosvete, nauke i tehnološkog razvoja.
} 
novine $\mathrm{u}$ koncepciji obrazovanja poput proširivanja učenja van školskih okvira i upotrebe različitih izvora znanja. Alternativni oblik obrazovanja svakako predstavlja korišćenje muzeja, koji dobija na značaju upravo usled promena u shvatanju savremenog obrazovanja i procesa učenja. Naime, poslednjih decenija XX veka pred muzej se postavlja zahtev da se preobrazi i bude obrazovni i zabavni ambijent za sve jer se u njemu vidi prilika za efikasno i doživotno učenje u svrhu građenja kvalitetne budućnosti. Kao čuvar istorije i kulture, muzej je svakako jedan od značajnih izvora znanja i učenja u ljudskoj zajednici (Žilber, 2005).

Muzej bi trebalo da bude od velikog značaja u razvoju motivacije za učenje i intelektualne radoznalosti, pružanju podrške i uvećanju želje za učenjem. U tom smislu, obrazovnu ulogu muzeja ne treba svoditi jedino na otvaranje izložbenog prostora i prenošenje informacija jer se pokazuje da pedagogija transmisije ne pruža dovoljno dobre rezultate ni u školskoj praksi, pa tako ni u muzeju (Milutinović, Gajić i Klemenović, 2008). Drugim rečima, obrazovnu funkciju muzeja ne treba ograničavati tradicionalnim okvirima, već, naprotiv, isticati njene široke mogućnosti za aktivno učenje, komunikaciju sa posetiocima te sticanje i bogaćenje njihovog iskustva. Otuda se danas - kao bazična teorijska osnova obrazovnog rada muzeja - ističe konstruktivistička teorija. Osnovna namera autorki ovog rada jeste da se prikaže na koji način se muzej, posredstvom konstruktivističke teorijske osnove u svom obrazovnom radu, oblikuje u proaktivnu obrazovnu instituciju i podsticajnu sredinu za učenje. 


\section{MUZEJ KAO OBRAZOVNA SREDINA}

Danas je vaspitno-obrazovna uloga muzeja priznata, kako od strane muzejskih stručnjaka, tako i od strane socijalnog okruženja (HooperGreenhill \& Moussouri, 2002). Iako se još početkom XIX veka govorilo o obrazovnom potencijalu muzeja, ova funkcija dobija na značaju tokom XX veka, uporedo sa formiranjem društvenih nauka kao akademskih predmeta $\mathrm{i}$ kreiranjem moderne teorije ljudskog razvoja. U literaturi se (Hajn, 2014) ističe da se među prvima za muzej kao obrazovnu instituciju zalagao kustos Džordž Braun Gud (George Brown Goode) naglasivši da muzej kao društvena institucija treba da doprinosi javnom obrazovanju. U kontekstu obrazovnih aktivnosti, znatan doprinos ostvarili su i progresivni i društvenopolitički pokreti čije metode podrazumevaju učenje od predmeta i sa njima, isticanje važnosti ispitivanja, korišćenje lokalnih materijala i delatnosti, kao i uvažavanje interesovanja i iskustva posetilaca. Prema Hajnu (Hein, 1998), muzeji predstavljaju sastavni deo obrazovne infrastrukture određenog društva i, stoga, imaju važnu ulogu da svojim obrazovnim radom prošire i obogate mesta za učenje najčešće svrstana u školske okvire.

U literaturi se (Bamberger \& Tal, 2007) muzeji ubrajaju među najpopularnija okruženja za učenje putem slobodnog izbora, tako da u većini zemalja predstavljaju osnovno mesto za učenje izvan škole. Ideja slobodnog izbora uključuje prirodu vanškolskog okruženja i omogućava odabir različitih strategija učenja, tema i prostora za učenje. Obrazovna sredina i uslovi učenja u muzeju se po mnogo čemu razlikuju od obrazovne sredine formalnih vaspitno-obrazovnih institucija noseći značajne potencijale za učenje pojedinaca, porodica i učenika (Hooper-Greenhill \& Moussouri, 2002; Milutinović, 2010). Naime, muzej se može označiti kao mesto igre i učenja, 
dosetljivosti i radosti, a može biti naročito značajan za razvoj motivacije za učenje i intelektualnu radoznalost, pružanje podrške i uvećanje želje za učenjem. Takođe, muzej pruža mnogobrojne informacije o društvenom nasleđu i kulturnim korenima, delujući na taj način u pravcu izgradnje kvalitetnih odnosa i socijalnog uključivanja pojedinaca, grupa, zajednica i kultura. Uz to, muzej utiče na razvoj osećaja i smisla za posmatranje, kreativno i kritičko mišljenje (Milutinović i sar., 2008). Kako Hajn (Hein, 1995) navodi, muzej je izuzetna sredina za učenje, čija se moć i uticaj potvrđuje kroz oblikovanje prilika da posetioci bez prinude uče vlastitim tempom, postavljaju pitanja, sarađuju i razmenjuju stečena znanja i da na različite načine zadovolje svoju radoznalost. Stoga, muzej čija je težnja da podstakne proces učenja, monolog zamenjuje dijalogom između posetilaca, te između njih i konkretnih predmeta. U tom kontekstu, razvija se radoznalost, srazvija se želja za traganjem i otkrivanjem, slobodnim izražavanjem i prenošenjem iskustava. Specifična dimenzija učenja u muzeju ostvaruje se putem delovanja, slobodne komunikacije i socijalne interakcije realizovane $u$ slobodnom vremenu između posetilaca i muzejske sredine (Milutinović, 2010). Otuda je pri određivanju osnovne uloge muzeja u društvu značajno prihvatiti principe o kojima je pisao Anderson (prema: Milutinović i sar., 2008): 1. muzej je institucija koja predstavlja opšte dobro i nalazi se u službi društva; 2. muzej je obrazovna institucija; 3. muzej kreira formalne i informalne situacije za učenje tokom čitavog života; 4. svaki pojedinac ima jednaka prava da participira u životu i radu muzeja. Krajnji cilj muzeja jeste kontakt sa zajednicom, slobodna interakcija i kvalitetno učenje posetilaca u svrhu njihove pripreme za doživotno učenje. 


\section{KONSTRUKTIVISTIČKA TEORIJSKA ORIJENTACIJA}

Danas su u pedagoškoj literaturi prisutne različite teorije koje preispituju i objašnjavaju pitanja obrazovanja i učenja a najčešće se navode bihejviorističke, kognitivne i konstruktivističke teorije (Jukić, 2013). Kako mnogi autori ističu (Hein, 1995; Hooper-Greenhill \& Moussouri, 2002; Milutinović i sar., 2008; Žilber, 2005), nema sumnje da su u savremenom procesu učenja i obrazovnom diskursu dominantne konstruktivističke ideje. Pojava ovih ideja sa sobom povlači niz promena u obrazovanju i procesu učenja, tako da su one od velikog značaja za razvoj pedagoške nauke u XXI veku (Jurić i sar., 2001). Naime, konstruktivistički pristup je suprotan empirističko-redukcionističkom pristupu tradicionalne didaktike koji učenje i poučavanje posmatra u vidu prenosa i zapamćivanja sadržaja i informacija (Milutinović, 2010). Konstruktivizam se zasniva na ključnim pretpostavkama postmodernističkih ideja a, kao teorija saznanja, objašnjava da je proces sticanja znanja i poimanje sveta lična tvorevina pojedinca i proizvod konstrukcije (Jukić, 2013; Milutinović i sar., 2008).

Konstruktivističko shvatanje procesa obrazovanja i učenja pretpostavlja primenu svih raspoloživih resursa i promenu percepcije prostora i vremena za učenje. U tom okviru, ova filozofija obrazovanja svaki životni i radni prostor posmatra kao potencijalnu sredinu za učenje (Milutinović i sar., 2008), a sam proces učenja karakteriše kao samostalan i aktivan proces koji se ostvaruje kroz socijalnu interakciju (Jukić, 2013). Reč je o uverenju da se učenje unutar konstruktivističke perspektive temelji na ličnoj konstrukciji i rekonstrukciji znanja, ali i da se odvija i nastaje u interakciji sa socijalnim i fizičkim okruženjem, uz uticaj prethodnog znanja (Milutinović, 2010; Mušanović, 2000). Otuda se u literaturi (Jonassen, 1991) ističe da je, radi 
uspešnog odvijanja procesa učenja i realizovanja konstruktivističkog dizajna nastave, neophodno uvažiti sledeće principe: 1. omogućiti višestruke prilaze i prikaze realnosti; 2. akcentovati izgradnju znanja a ne njegovu reprodukciju; 3. konstrukcija znanja može se olakšati ukoliko se predstavlja prirodna kompleksnost stvarne okoline i sveta; 4. obezbediti raznovrsne autentične zadatke; 5. osigurati realnu sredinu za učenje uz izostavljanje unapred propisanih nastavnih strategija; 6. podsticati refleksivnu praksu; 7. konstrukciju znanja zasnivati na sadržaju i kontekstu; 8. podsticati konstrukciju znanja kroz društvene odnose i interakciju.

Za razvoj različitih konstruktivističkih perspektiva $\mathrm{u}$ oblasti obrazovanja najzaslužnije su: Djuijeva (John Dewey) teorija iskustva, mišljenja i učenja; Pijažeova (Jean Piaget) razvojna teorija; socio-kulturna teorija Vigotskog (Lev Vыgotskiй); zatim Brunerova (Jerome Bruner) koncepcija učenja, kategorizacije i potrage za značenjem i u novije vreme Gardnerova (Howard Gardner) teorija vešestrukih inteligencija (Milutinović i sar., 2008). Navedene teorijske orijentacije bazirane su na iskustu i danas ostvaruju značajan uticaj na vaspitno-obrazovni rad u muzeju.

\section{PRIMENA TEORIJA UČENJA ZASNOVANIH NA ISKUSTVU U OBRAZOVNOM RADU MUZEJA}

Američki filozof Djui, kao začetnik pragmatizma, doprineo je artikulaciji i razvoju konstruktivističke epistemologije i pedagogije (Milutinović i sar., 2008). Djui (1970) je tvrdio da svaka ideja pojedinca predstavlja produkt društvene sredine, kao i da saznanje zavisi od subjekta koji saznaje i ima izvor u njegovom iskustvu. Prema njegovom mišljenju, iskustvo predstavlja glavni izvor procesa saznavanja. Pri tome se njegova 
koncepcija obrazovanja zasniva na rekonstrukciji iskustva budući da je obrazovanje „takva rekonstrukcija i reorganizacija iskustva koja uvećava značaj iskustva i sposobnost da upravlja tokom daljeg iskustva” (Djui, 1970: 57). Osim iskustva, kao polazne osnove u obrazovanju, Djui ističe samostalnost $\mathrm{i}$ aktivnost učenika u svakom obrazovnom postupku. Kao protivnik davanja znanja u gotovom obliku, on predlaže da u obrazovanju treba poći od iskustva i sposobnosti učenika, i imati u vidu da su oni aktivna bića sposobna da misle i rekonstruišu vlastito iskustvo. Uz to, u literaturi se (Milutinović, 2008) ističe da Djui interes i radoznalost posmatra kao snažnu motivacionu snagu za učenje. Insistirajući na unutrašnjoj motivaciji učenika, upravo interes izdvaja kao intrinzički motiv i pokretačku snagu učenika kao aktivnog bića. Po svemu sudeći, osnovno načelo obrazovanja i nastave jeste „učenje putem delanja” i „učenje iz iskustva” (Milutinović i sar., 2008). Predstavljene ideje poznatog američkog filozofa i pedagoga danas su od velike važnosti za obrazovni rad u muzeju. „Učenje putem delanja”, kao osnovno načelo obrazovanja, imalo je značajan uticaj na obrazovnu praksu muzeja, a konkretno se odnosi na direktnu manipulaciju predmetima i eksperimentisanje sa realnim objektima. Dalje, veliki značaj pripisuje se učenju iz iskustva: veoma je važno oblikovati obrazovnu sredinu muzeja tako da omogućava sticanje iskustva iz prve ruke (Milutinović i sar., 2008). Pri tome, iz Djuijeve koncepcije obrazovanja proizlazi sledeće: da bi okruženje muzeja i muzejsko iskustvo imali obrazovni karakter, neophodno je, osim upotrebe predmeta, aktivirati um posetioca. Takođe, stečena iskustva $u$ muzeju moraju biti interesantna $\mathrm{i}$ intenzivna, ali pre svega organizovana kako bi ispunila obrazovnu ulogu. 
Teorija kognitivnog razvoja švajcarskog psihologa i pedagoga Pijažea uticala je na razvoj konstruktivističke perspektive prema kojoj učenik aktivno rekonstruiše znanje na individualan način, a znanje se posmatra kao proaktivna konstrukcija organizma koji saznaje. Učenje i razvoj se razmatraju kao pitanja individualnog formiranja značenja, te se učenik posmatra kao aktivan pojedinac koji se putem asimilacije i akomodacije adaptira spoljašnjem svetu, i koji u tim procesima kreira nove saznajne strukture. Učenjem se obezbeđuje nastajanje novih struktura i unapređivanje starih (Milutinović, 2016). Konstrukcija upravlja mentalnim razvojem pojedinca, koji konstruiše svoju ličnost i saznanja o svetu kroz interakciju sa fizičkom i socijalnom sredinom. Uz to, pojedinac celokupno znanje iz spoljašnje sredine nadovezuje na već postojeća iskustva i saznanja. U osnovi Pijažeove teorije konstrukcija mentalnog razvoja odvija se po stupnjevima, a na svakom od njih vrši se rekonstrukcija onoga što je usvojeno na prethodnom stupnju (Milutinović i sar., 2008). Pijažeova teorija učenja i razvojnih stadijuma ima značajne implikacije na obrazovni rad u muzeju. Naime, iz njegove tvrdnje da proces mišljenja predstavlja internalizovanu aktivnost, može se izvesti pedagoška poruka prema kojoj svaki pojedinac mora biti aktivan i kreativan u izgradnji vlastitog znanja. Muzej kao obrazovna sredina treba da podstiče istraživanje, angažovanost posetilaca, te aktivno manipulisanje predmetima. Ili, konkretnije, muzej svojim posetiocima treba da omogući slobodno delovanje na okruženje i primenu i rukovanje fizičkim objektima (Milutinović, 2003).

Socio-kulturna teorija kognitivnog razvoja ruskog psihologa Vigotskog proces sticanja znanja poverava socio-istorijsko-kulturnom procesu; poreklo znanja je društveno, a socijalna sredina posmatra se kao 
ključan izvor razvoja. Prema socio-kulturnoj teoriji, biološki razvoj doprinosi dečjem razvoju, ali ključnu ulogu u tom procesu ima socijalno delovanje. Dakle, prema mišljenju Vigotskog, sve više mentalne funkcije proizašle su iz socijalnih odnosa a zatim postale funkcije ličnosti. Sve socijalne interakcije su, prema njegovom mišljenju, polazna tačka za rekonstruisanje prethodnog iskustva i znanja. Za razvoj psihičkog života, osim socijalne interakcije, važnu ulogu zauzima jezik kao oruđe mišljenja (Milutinović i sar., 2008). Prema Vigotskom (1977), jezik odnosno govor omogućava izgradnju kvalitetnih društvenih odnosa u socijalnom okruženju, osigurava polaznu strukturu za kognitivne aktivnosti, razvoj mišljenja te uobličavanje sopstvenih misli. Među bazičnim idejama Vigotskog svakako je ,zona narednog razvoja" koju objašnjava kroz dva razvojna stadijuma: prvi stadijum tiče se sposobnosti deteta da samostalno deluje bez pomoći odrasle osobe, dok se drugi stadijum može doseći samo uz pomoć sposobnijeg vršnjaka ili odraslog. Ovakva se shvatanja svakako mogu naći u obrazovnom radu muzeja, pri čemu se pred muzej postavljaju zahtevi za adekvatnom obrazovnom sredinom bogatom različitim ,građevinskim” materijalima koji uspostavljaju vezu sa svakodnevnim životom. Kada je reč o procesu učenja, Vigotski (1977) značajnu pažnju usmerava na socio-kulturne aktivnosti koje uključuju saradnju, pregovaranje, interakciju sa vršnjacima i razmenu ideja i saznanja. Učenje kroz saradnju i zajedničko dolaženje do rešenja predstavlja određeni doprinos muzejskom ambijentu u pogledu kreiranja uslova za učenje svih posetilaca i učesnika.

Američki psiholog i pedagog Bruner ostvario je snažan doprinos u području kognitivne psihologije. On je imao uticaj na razvoj konstruktivističke perspektive zagovarajući ideju o aktivnom procesu učenja 
u kojem učenik konstruiše nova znanja i ideje na osnovu postojećeg saznanja i iskustva. Pri razmatranju obrazovnog procesa, Bruner veruje da se on ne može svoditi na memorisanje i usvajanje znanja, već da bi trebalo rezultirati razumevanjem. U procesu sticanja znanja učenik treba da uloži kognitivni trud i uči putem otkrića kako bi stekao najkorisnije znanje. Bruner (2000) je naročitu pažnju posvetio socijalnom i kulturnom aspektu učenja ističući priču i narativne iskaze. Njegov uticaj na obrazovni rad muzeja ogleda se u idejama o značaju oblikovanju povoljnih uslova za učenje koji uključuju sprovođenje eksperimenata, učenje otkrivanjem, organizaciju sredine koja angažuje čula posetilaca (Milutinović i sar., 2008). Takođe, veliki značaj za učenje u muzeju ostvarila je Brunerova (2000) pretpostavka o četiri načina konstruisanja značenja putem iskustva, a to su: delovanje - preuzimanje veće kontrole nad sopstvenom umnom aktivnošću; refleksija - razumevanje i smisleno povezivanje naučenog; saradnja - razmena resursa svih pojedinaca uključenih u proces sticanja znanja i kultura - kao način života i razmišljanja koji se konstruiše i institucionalizuje. Uopšte uzev, pomenute teorije učenja zasnovane na iskustvu imale su značajan doprinos $u$ razvoju konstruktivističke teorije, čiji pristup učenju preovladava u novijim istraživanjima o učenju u muzeju (Falk et al., 2004; Hein, 1998; Gajić i Milutinović, 2011).

\section{OBRAZOVNI RAD MUZEJA U SVETLU KONSTRUKTIVISTIČKE TEORIJE}

Određene promene u obrazovnom radu muzeja koje uključuju pomak od transmisivnih ka konstruktivističkim pedagoškim osnovama doprinele su pomeranju težišta učenja sa muzejskog predmeta na aktivnost pojedinca odnosno posetioca. U ovakvom okruženju učenje je dobrovoljan i 
samousmeravajući proces koji ne zavisi od spoljašnjeg autoriteta (HooperGreenhill \& Moussouri, 2002; Milutinović, 2010). Dakle, prema konstruktivističkoj teorijskoj osnovi u procesu učenja i saznavanja, učenik mora biti u poziciji aktivnog subjekta, što u muzeju kao obrazovnoj sredini znači da pažnju treba usmeriti na posetioca, a ne na sadržaj muzeja. Uz to, proces učenj posmatra se kao konstrukcija znanja, odnosno kao produkt aktivne mentalne konstrukcije. Stoga se danas sve više govori o paradigmi „stvaranja značenja” kao o novom načinu saznavanja i sticanja iskustava u muzeju (Hein, 1995; Milutinović i sar., 2008). U okviru ove paradigme razvijaju se različite strategije, metode i procedure za procenu učenja, a sadržaj izložbe se povezuje sa svakodnevnim životnim situacijama, prilagođava se potrebama posetilaca i izlaže na interesantan način. Uz to, u literaturi se (Žilber, 2005) ističe da obrazovanje i učenje u muzeju treba da se odvija kroz diskusiju, komunikaciju i istraživanje u svrhu razvoja identiteta, proširenja postojećeg i sticanja novog znanja.

U tom okviru, konstruktivistička teorijska osnova nudi mnoge pogodnosti za obrazovni rad u muzeju. Reč je o podsticajima u pravcu oblikovanja otvorene, prijatne i bogate sredine za učenje koja polazi od potreba i interesovanja posetilaca. Ta teorijska osnova podstiče komunikaciju, socijalnu interakciju, što posetiocima omogućava da kroz saradnju sa drugima konstruišu i oblikuju stvarnost (Milutinović i sar., 2008). Za obrazovni rad u muzeju veoma su značajne i misli Djuija (Djui, 1970), koji je naglašavao učenje iz iskustva ističući važnu ulogu urođenih težnji pojedinaca za istraživanjem, rukovanjem predmetima, materijalima i konstruisanjem. Hajn (Hein, 1995) napominje da konstruktivistički muzej, stavljajući u prvi plan aktivno konstruisanje znanja putem ličnih metoda 
učenja, formira sredinu koja se može prilagoditi različitim saznajnim srukturama posetilaca. Naime, konstruktivistička teorijska osnova $\mathrm{u}$ obrazovnom radu muzeja ukazuje na to da ne postoje dva pojedinca koja mogu imati identičan pogled na stvarnost, te da svaka individua gradi vlastitu sliku sveta (Gajić i Milutinović, 2011). Drugačije rečeno, svaki posetilac ima svoje životno iskustvo, svoj stil i tempo učenja i druge individualne razlike od kojih zavisi proces saznavanja i razumevanja realnih predmeta. Kako bi muzej postao podsticajna sredina za učenje, on prvenstveno treba da razume individualne razlike i kvalitete među svojim posetiocima, te da uvažava njihovo već stečeno iskustvo i različite stilove učenja.

Hajn (Hein, 1995) piše da upotreba konstruktivističke obrazovne teorije u muzeju pretpostavlja odbacivanje shvatanja učenja kao procesa neposrednog prenošenja znanja sa kustosa na posetioca, te naglašava postojanje višestrukih puteva i modaliteta usvajanja znanja. Stoga se u svetlu konstruktivističke obrazovne teorije u muzeju podstiču različiti načini učenja što omogućava posetiocima da uspostavljaju višestruke veze sa materijalima i realnim predmetima. Stavljanjem posetioca $u$ aktivan položaj i omogućavanjem lične i socijalne konstrukcije znanja, obrazovna sredina sam proces učenja i saznavanja čini konstruktivnim činom. Takav proces učenja stavlja posetioce u priliku da samostalno izvedu zaključke o značenju i značaju izložbe. Upravo aktivno izlaganje sadržaja predstavlja put ka kvalitetnijem učenju i realizaciji obrazovne uloge muzeja, jer interakcija pokreće posetioce na razmišljanje, iznošenje vlastitog, ali i uvažavanje tuđeg mišljenja. Na taj način, prema mišljenju Hajna (Hein, 1998), pedagoški sadržaj muzeja postaje pristupačan na više načina, približen i povezan sa svakodnevnim životnim situacijama, te vođen prethodnim saznanjima 
posetilaca. Tako, pedagoški rad muzeja u svetlu konstruktivističke teorijske osnove pruža mogućnost za uspostavljanje bliskih veza između postojećeg i novog znanja. Takođe, proces učenja u muzeju postaje efikasan, jer kroz mnogobrojne načine posetiocu može priuštiti da se poveže s izložbom i da usvoji nove informacije. Dakle, u okviru nove paradigme, u fokusu svakog procesa učenja nalazi se posetilac/učenik, a ne sadržaj koji treba usvojiti. Iz tog proizlazi da u obrazovnom radu muzeja pažnju treba usmeriti na posetioca a ne na sadržaj izložbe, jer se pre svega muzej (Hein, 1995; Žilber, 2005) bavi ljudima a ne predmetima.

\section{UČENJE U MUZEJU: REZULTATI ISTRAŽIVANJA}

Neka istraživanja (Gajić i Milutinović, 2011) pokazuju da primena konstruktivističke teorije u muzeju na različite načine pruža podsticaj za učenje jer takve obrazovne prilike omogućavaju diferencirani pristup i pružaju mnogobrojne izazove. U pitanju je to da različiti načini interpretacije sadržaja i različite perspektive podržavaju različita poimanja muzejskih predmeta, dok pružanje prilika za mnogobrojne načine saznavanja (slika, zvuk, reč, dodir) i uvažavanje različitih stilova učenja doprinosi aktivnom uključivanju posetilaca. Dalje, konstruktivistička orijentacija na učenje delanjem rezultira pobuđivanjem interesovanja, ali i razvojem motoričkih veština kroz modelovanje. Rezultati nekih istraživanja (Falk et al., 2004) pokazuju da posetioci u muzeju uviđaju značaj interaktivnih iskustava $u$ procesu sticanja znanja i da razumeju i cene interaktivnu prirodu izlaganja sadržaja. Naime, oni opažaju da se interaktivnim izložbama podstiču razgovor, saradnja, komunikacija i učenje kroz delanje, te pruža povratna informacija i znanje primenljivo u svakodnevnom životu. Takođe, nalazi 
pokazuju da interaktivna iskustva menjaju percepciju posetilaca o muzejima kao „starim” i „zapuštenim” mestima i ohrabruje svest o muzeju kao podsticajnoj sredini za učenje.

Pojedine studije (Andre, Durksen \& Volman, 2017) fokusirale su se na identifikovanje muzejskih aktivnosti i strategija koje podstiču i podržavaju učenje dece koristeći sociokulturno objašnjenje učenja. Ta studija pruža uvid u jezgro istraživanja o iskustvima muzejskih posetilaca i znanja koja su ustanovljena tokom poslednje decenije istraživanja učenja $\mathrm{u}$ muzeju. Rezultati ukazuju na značaj kreiranja okruženja za učenje koje omogućava primenu različitih strategija učenja i aktivnosti kombinujući drugačije vrste interaktivnosti. Kao najčešće aktivnosti u muzejima navode praktične, koje uključuju individualno i samoupravljeno angažovanje (interakciju deteta sa okolinom) i vođstvo od strane odraslih (interakciju deteta sa odraslima/vršnjacima). Među dominantnim poželjnim aktivnostima izdvajaju se i interaktivne izložbe uz pomoć tehnologije, naročito kroz upotrebu mobilnih aplikacija i interaktivnih igara. Dalje, studija je ukazala na to da je važno da se proces učenja ostvaruje kroz saradnju i učestvovanje u programima ili radionicama ili kroz primenu obrazovnih materijala i predmeta. Istraživanje ukazuje da strategije i aktivnosti podsticanja pozitivno utiču na stavove prema nauci i konceptima znanja, razumevanje, timski rad i saradnju u grupi, komunikacijske i veštine kritičkog mišljenja. Uz to, interaktivne strategije i aktivnosti često izazivaju radoznalost, uzbuđenje, diskutovanje i istraživanje. Uopšte uzev, rezultati studije ukazuju na to da transformacija okruženja muzeja - od izložbi o nečemu ka izložbi za nekoga pretpostavlja praktične aktivnosti, komunikaciju, igru, interakciju sa odraslima i vršnjacima i primenu nekih oblika tehnologije. 


\section{ZAKLJUČAK}

Namera autorki ovog rada je da se ispita značaj konstruktivističke teorijske osnove kao jednog od načina dizajniranja obrazovnog rada muzeja koji pomera fokus sa određenog predmeta i sadržaja muzeja ka posetiocu kao subjektu i aktivnom biću. U središtu ovakvog okruženja nalaze se interaktivne metode učenja; pažnja je usmerena na saradnju i dvosmernu komunikaciju između posetilaca, i posetilaca i kustosa. Istraživanja su (Andre et al., 2017) potvrdila da interaktivne strategije i aktivnosti izazivaju radoznalost i uzbuđenje, pozitivno utiču na stavove prema nauci i koncepte znanja posetilaca, pokreću diskusiju i istraživanje, timski rad i saradnju, te razvijaju komunikacijske sposobnosti i veštine kritičkog mišljenja. Uz to, sadržaj se prezentuje na zanimljiv i pristupačan način u odnosu na interesovanja, afinitete i indtividualne karakteristike posetilaca. Uvažavajući njihova interesovanja, potrebe i želje, tempo i stil učenja, konstruktivistička obrazovna sredina muzeja obezbeđuje autentična iskustva učenja.

Na osnovu prethodnih analiza, zaključuje se da muzej, kao sredina za učenje, svojim posetiocima može pružiti značajne pedagoške podsticaje. Naime, muzejska obrazovna sredina, koja omogućava kontakt sa zajednicom, slobodnu interakciju i kvalitetno učenje posetilaca, pogodna je za implementaciju interaktivnih strategija učenja, te tako ima priliku da postane predvodnik obrazovnih promena $\mathrm{i}$ novina $\mathrm{u}$ poimanju procesa učenja. Svakako da je pitanje učenja u muzeju izuzetno složen fenomen koji zahteva dalja istraživanja i procene, posebno u uslovima nepostojanja dovoljno validnih $i$ pouzdanih instrumenata koji odgovaraju jedinstvenoj kontekstualnoj realnosti učenja po slobodnom izboru (Folk, Dirking \& 
Adams, 2014). Rezultati takvih istraživanja bili bi veoma značajni za dalju transformaciju muzejskog okruženja u podsticajnu sredinu za učenje.

\section{LEARNING IN A MUSEUM IN LIGHT OF CONSTRUCTIVIST THEORETICAL BASIS}

\section{Abstract}

The paper starts from the viewpoint that museums have a significant potential for learning. More recently, the impact of constructivist theory on the museum is significant, which is particularly reflected in the field of educational work. In this context, the text analyzes theoretically the constructivist approach to education and learning in the museum. The aim of the paper is to consider possibilities and significance of the constructivism application in educational work and the learning process in the museum. Firstly, the key points of constructivism are being examined, giving an overview of experience-based theories that have left a significant mark in the educational practice of the museum. Also, there are presented the research findings on the effects of the constructivist theory application in the educational work of the museum. It is concluded that the application of constructivism as the theoretical basis of educational work in museums brings significant pedagogical incentives: the museum adapts to the needs and interests of visitors, museum experiences are approaching and connecting with everyday life, the contents are exposed in an interesting way, thus providing the authentic learning experiences.

Key words: constructivism, museum, education, learning. 


\section{REFERENCE}

Andre, L., Durksen, T., \& Volman, L. M. (2017). Museum as avenues of learning for children: A decade of research. Learning Environments Research, 20(1), 47-76.

Bamberger, Y., \& Tal, T. (2007). Learning in a personal context: Levels of choice in a free choice learning environment in science and natural history museums. Science Education, 91(1), 75-95.

Bruner, Dž. (2000). Kultura obrazovanja. Zagreb: Educa.

Djui, Dž. (1970). Vaspitanje i demokratija - uvod u filozofiju vaspitanja. Cetinje: Obod.

Falk, J. H., Scott, C., Dierking, L., Rennie, L., \& Jones, M. C. (2004). Interactives and visitor learning. Curator: The Museum Journal, 47(2), 171-198.

Folk, H. Dž., Dirking, D. L., \& Adams, M. (2014). Život u društvu koje uči: muzeji i učenje po slobodnom izboru. U: Š. Makdonald (ur.), Vodič kroz muzejske studije (str. 465-488). Beograd: Clio.

Gajić, O. i Milutinović, J. (2011). Vaspitanje umetnošću - emancipatorni potencijal u društvu znanja. U: G. Gojkov i A. Stojanović (ured.), Daroviti u procesu globalizacije, Zbornik 16 (str. 173-184). Vršac: Visoka škola strukovnih studija za obrazovanje vaspitača Mihailo Pavlov.

Hajn, I. Dž. (2014). Muzejska edukacija. U: Š. Makdonald (ur.), Vodič kroz muzejske studije (str. 489-507). Beograd: Clio.

Hein, E. G. (1995). The constructivist museum. Journal for Education in Museum, 16, 21-23.

Hein, E. G. (1998). Learning in the Museum. London: Routledge.

Hooper-Greenhill, E., \& Moussouri, T. (2002). Researching learning in museum and galleries 1990-1999: A bibliographic review. Leicester: RCMG.

Jonassen, D. (1991). Evaluation constructivist learning. Educational Technology, 36(9), 28-33. 
Jukić, R. (2013). Konstruktivizam kao poveznica poučavanja sadržaja prirodnoznanstvenih i društvenih predmeta. Pedagogijska istraživanja, 10(2), 241-263.

Jurić, V., Mušanović, M., Stančić, S. i Vrgoč, H. (2001). Koncepcija razvojne pedagoške djelatnosti stručnih suradnika. Zagreb: Ministarstvo prosvjete i sporta, $\mathrm{RH}$.

Milutinović, J. (2003). Informalno obrazovanje - pojmovni okvir i karakteristike. Pedagoška stvarnost, 49(5-6), 394-407.

Milutinović, J. (2008). Ciljevi obrazovanja $i$ učenja u svetlu dominantnih teorija vaspitanja 20. veka. Novi Sad: Savez pedagoških društava Vojvodine.

Milutinović, J. (2010). Učenje u muzeju. Povijest u nastavi, 16(2), 217-229.

Milutinović, J. (2016). Socijalni i kritički konstruktivizam u obrazovanju. Novi Sad: Filozofski fakultet.

Milutinović, J., Gajić, O. i Klemenović, J. (2008). Muzeji kao centri učenja: Umetnička dela u funkciji razvoja percepcije i dečjeg stvaralaštva. U: B. Kulić i Đ. Randaco (ur.), Oseti umetnost: Interkulturalno iskustvo u muzejskoj edukaciji (str. 119-265). Novi Sad: Galerija Matice srpske.

Mušanović, M. (2000). Konstruktivistička teorija i obrazovni proces. U: Didaktični in metodični vidiki nadaljnjega razvoja izobraževanje (str. 28-35). Maribor: Univerza v Mariboru, Pedagoška fakulteta.

Vigotski, L. S. (1977). Mišljenje i govor. Beograd: Nolit.

Žilber, K. (2005). Muzej i publika. Beograd: CLIO. 